AWEJ for Translation \& Literary Studies, Volume3, Number4. October 2019

DOI: http://dx.doi.org/10.24093/awejtls/vol3no4.7

Pp.86 -97

\title{
Shakespeare's Romeo and Juliet: Maladjustment of Masculine and Feminine Traits as the True Cause of Tragedy
}

\section{Chatta Bala Swamy}

Department of Management, College of Business Administration, Prince Sattam Bin Abdulaziz University, Al Kharj, Saudi Arabia.

\section{Paturi Madhuri Devi}

Department of Management, College of Business Administration, Prince Sattam Bin Abdulaziz University, Al Kharj, Saudi Arabia

\section{Koppada Venugopal}

Department of Management, College of Business Administration, Prince Sattam Bin Abdulaziz University, Al Kharj, Saudi Arabia

\begin{abstract}
The chief aim of this article is to bring about a better understanding of Shakespeare's drama Romeo and Juliet by tracing the protagonists' actions to the maladjustment of masculine and feminine traits. As per the accepted psychic gender principles, a man possesses more reason and less emotion, and a woman, more emotion and less reason. The context of a woman with more reason and a man with more emotion coming together in a peculiar relationship is the maladjustment of their psychic personalities. Tragedy, from this point of view, is the portrayal of the unbalanced psychological natures of men and women, which has disastrous consequences. The paper seeks to prove that neither Romeo nor Juliet is responsible for the tragedy as individuals. It is the somewhat peculiar relationship between them that influences each other's personalities and leads them to disaster. The paper also throws light on how a mere erotic sexual love metamorphoses into the sacrificial divine love.
\end{abstract}

Keywords: erotic love, maladjustment, personality, relationship, tragedy

Cites as: Swam, C. B., Devi, P. M., \& Venugopal, K. (2019). Shakespeare's Romeo and Juliet: Maladjustment of Masculine and Feminine Traits as the True Cause of Tragedy. Arab World English Journal for Translation \& Literary Studies3 (4) . DOI: http://dx.doi.org/10.24093/awejtls/vol3no4.7 